\title{
DOES THE EMPEROR HAVE FINANCIAL CRISIS CLOTHES? REFLECTIONS ON THE LEGAL BASIS OF THE EUROPEAN BANKING AUTHORITY
}

\section{(2011) Modern Law Review (forthcoming)}

\section{Dr. Elaine Fahey*}

KEYWORDS: European Union law - Financial crisis - European Banking Authority Internal Market - Harmonisation - Institutional design - Article 114 TFEU - EU Agencies- European Supervisory Authority - Legislative Competence

The European Union institutional package launched in response to the financial crisis used Article 114 TFEU as its legal basis. The author explores the legal basis for one of the European Supervisory Authorities recently established- the European Banking Authority (EBA). The use of Article 114 TFEU, the main Treaty basis used to harmonise laws in order to further the internal market, as the foundation for the EBA, is considered in detail. A paradox of contemporary EU Institutional law is assessed here, considering whether on the one hand, the EBA is functionally both too narrow and too broad as a matter of law, while on the other hand, it may prove to be central to restoring confidence in EU regulatory powers, rendering it "too big to fail," despite its slender foundations in Article 114 TFEU.

\section{Introduction}

While the precise causes of the global financial crisis may still be the subject of reflection, the European Union responded to the crisis principally with an institutional or "supervisory architecture" package: a European System of Financial Supervision, comprising several institutions known as European Supervisory Authorities (ESA's). ${ }^{1}$ A curiosity arises from the fact that all of these institutions now enacted into EU law are grounded in Article 114 TFEU as their legal base. ${ }^{2}$ Article 114 TFEU was and is the

\footnotetext{
* Visiting Max Weber Fellow, European University Institute, Florence, Italy and Assistant Lecturer, School of Social Sciences and Law, Dublin Institute of Technology, Ireland. Email: Elaine.fahey@eui.eu. I am very grateful to the conference discussants at the European University Institute conference "2007-2010 Financial and Economic Crisis: Causes, Consequences, and Policy Responses" (April 2010) and to Ester Herlin-Karnell, Stephen Carruthers and the reviewers for their comments. All errors are solely those of the author.

${ }^{1}$ Comprising a European System of Financial Supervisors (ESFS) and A European Systemic Risk Board (ESRB), consisting of a network of national financial supervisors working in tandem with new European Supervisory Authorities (ESA's), created by the transformation of existing Committees for the banking securities and insurance and occupational pensions sectors: European Banking Authority $\operatorname{COM(2009)~501;~}$ European Insurance and Occupational Pensions Authority (COM(2009) 502 final); European Securities and Markets Authority (COM(2009) 503) all dated 23.9.2009; European Systemic Risk Board (COM(2009) 499, 23.9.2009). See, for a comprehensive survey, Ferran "Understanding the New Institutional Architecture of EU Financial Market Supervision" (20 November 2010), available at http://ssrn.com/abstract=1701147.

${ }^{2}$ Referred to as Article 114 Treaty on the Functioning of the European Union (TFEU) (ex. Article 95 EC).
} 


\section{DOES THE EMPEROR HAVE FINANCIAL CRISIS CLOTHES? REFLECTIONS ON THE LEGAL BASIS OF THE EUROPEAN BANKING AUTHORITY}

controversial "problem child" of the Laeken Declaration ${ }^{3}$ and remains the most commonly used legal basis to harmonise laws in order to further the internal market. Article 114 TFEU has been employed again recently as the central legal basis to resolve Europe's institutional and regulatory shortcomings. Yet there is no precedent for the institutional design on the scale enacted arising from this slender legal base. ${ }^{4}$

One of the several institutions recently established was a European Banking Authority (EBA), the legal basis of which is the subject of analysis here. The EBA alone is selected from these institutions on the grounds of space but also by reason of its high-profile status, its functionally-singular activity and its direct role as to the banking and finance industry. ${ }^{5}$ It is contended that the use of Article 114 TFEU as the legal basis for the EBA raises many difficulties given the particularly limited tasks and powers conferred on the EBA. Equally, however, the systemic reform package may in fact go beyond anything previously contemplated or considered as lawful pursuant to Article 114 TFEU. The EBA is argued here to be functionally both too narrow and too broad as a matter of EU institutional and constitutional law. At a time of crisis, a close examination of the EBA may also indicate that the Emperor lacks financial crisis clothes and that a gap exists between what is politically and economically desirable and constitutionally possible. However, the operation and success of such agencies may bring stability, global cohesion and popular confidence in respect of European regulatory powers. Grand institutional reforms, not unlike large banks, may prove to be "too big to fail". This paradox of contemporary European institutional law is explored here.

The background to the adoption of the Regulation is considered firstly, followed by an outline of the details of the Regulation consideration of the state of the law as to Article 114 TFEU and the design of EU agencies or institutions. This application of this caselaw to the EBA is then considered.

\section{Background to the EBA}

First and foremost, in the aftermath of the collapse of Lehman Brothers in October 2008 the President of the European Commission asked Jacques de Larosière, a former Managing Director of the IMF and former Governor of the Bank of France, to chair a High Level Group to examine the future of European financial regulation and

\footnotetext{
${ }^{3}$ Laeken European Council, Laeken declaration on the future of the Union, SN 273/01, 15.12.2001: see Weatherill "Competence and Legitimacy" in Barnard and Odudu eds., The Outer Limits of European Union Law (Hart, 2009) p. 17.

${ }^{4}$ Moreover, the Commission had committed to quelling the growth of new EU agencies back in 2005Draft Interinstituitonal Agreement on the operating framework for the European regulatory agencies $\operatorname{COM(2005)} 59$ final. See the critique of Griller \& Orator "Everything under control? The "way forward" for European agencies in the footsteps of the Meroni doctrine" (2010) 35 European Law Review 3, at 5.

${ }^{5}$ Although each of the proposed ESA's is rooted in Article 114 TFEU and much of the analysis could apply mutatis mutandis to the other ESA's as regards their structures and powers.
} 


\section{DOES THE EMPEROR HAVE FINANCIAL CRISIS CLOTHES? REFLECTIONS ON THE LEGAL BASIS OF THE EUROPEAN BANKING AUTHORITY}

supervision, which published its report in early $2009 .{ }^{6}$ According to de Larosière, Governments planning for or negotiating over the rescue of cross-border banks did not have access to the same comprehensive information set. ${ }^{7}$ At the London G20 summit in April 2009, it was agreed to take a number of steps to reform the international financial system, to reshape regulatory systems, to establish supervisory colleges and to extend regulation and oversight to all systemically important financial institutions, instruments and markets. $^{8}$ In the wake of the de Larosière Report, the Commission presented a Communication in May 2009, setting out a vision for an architectural package. This package consisted of a European System of Financial Supervisors consisting of a network of national financial supervisors working in tandem with new European Supervisor Authorities (ESA) created by transforming the existing European Supervisory Committees in Banking, Securities and Insurance ${ }^{9}$ into a European Banking Authority (EBA), a European Insurance and Occupational Pensions Authority and a European Securities and Markets Authority. ${ }^{10}$ Also a European Systemic Risk Board (ESRB) has been enacted to monitor and assess potential threats to financial stability. These bodies were to constitute an overarching framework for financial supervision combined with expertise of local micro-prudential supervisory bodies closest to the institutions operating in their jurisdictions. ${ }^{11}$ The proposals were swiftly enacted into law and the Authorities are to begin work in 2011, on schedule.

The regulation of finance and banking is currently the subject of an extraordinary range of legislative initiatives in more than thirty areas- as to, for example, Credit Rating Agencies, Corporate Governance, Derivatives, Short selling and Hedge funds. ${ }^{12}$ The EU

\footnotetext{
${ }^{6}$ The High Level Group on Financial Supervision in the EU: De Larosiere Report (Brussels, 25 February, 2009); Alford "The Lamfalussy Process and EU Bank Regulation: Another Step on the road to PanEuropean Regulation" (2006) 25 Annual Review of Banking \& Finance Law 389. See also Alford "The use of colleges of regulators under European Union banking law" (2009) 24)(7) Journal of International Banking Law and Regulation 355.

7 Writing in 2006, Garcia and Nieto expressed concerns about the need to increase commitment to information exchange and to co-ordination of action between home and host state supervisors and other regulators in the EU: "Banking crisis management in the European Union: Multiple regulators and resolution authorities" (2005) 6(3) Journal of Banking Regulation 206.

${ }^{8}$ G20 Action Plan (31 March 2009)

“http://www.g20.org/Documents/g20_washington_actionplan_progress_140309.pdf.

${ }^{9}$ Committee of European Banking Supervisors, Committee of European Insurance and Occupational Pensions Supervisors and the Committee of European Securities Regulators.

${ }^{10}$ See above fn. 1.

11 See also the supporting powers set out in the Omnibus Directive 2010/78/EU providing supporting provisions for the ESA's: Amending Directives 1998/26/EC, 2002/87/EC, 2003/6/EC, 2003/41/EC, 2003/71/EC, 2004/39/EC, 2004/109/EC, 2005/60/EC, 2006/48/EC, 2006/49/EC, and 2009/65/EC in respect of the powers of the European Banking Authority, the European Insurance and Occupational Pensions Authority and the European Securities and Markets Authority and the Recitals included therein.

${ }^{12}$ See Annex 1 of Communication from the Commission to the European Parliament, Council, European Economic and Social Committee and the European Central Bank Regulating Financial Services for Sustainable Growth $\operatorname{COM(2010)~} 301$ final, enumerating thirty measures).
} 


\section{DOES THE EMPEROR HAVE FINANCIAL CRISIS CLOTHES? REFLECTIONS ON THE LEGAL BASIS OF THE EUROPEAN BANKING AUTHORITY}

Institutions are alive to the popular support now for regulation. ${ }^{13}$ Serious momentum is thus gathering to alter existing legal and regulatory rules and the EBA forms only one element in a wide-ranging package of measures.

And so the question arises as to the form of constitutional clothing that the EU has to weather this current storm of regulatory change. Prior to considering the question of competence, an outline of the activities and powers of the EBA is attempted here firstly, prior to an analysis being conducted of its legal basis, as well as relevant caselaw.

\section{The EBA Regulation: Structures, Functions and Powers}

\section{Structures and functions}

In the Regulation establishing the EBA, ${ }^{14}$ it is endowed with legal personality ${ }^{15}$ and has administrative and financial autonomy but is accountable to the Parliament and Council. ${ }^{16}$ Structurally, the EBA is comprised of a Board of Supervisors, a Management Board, a Chairperson, an Executive Director and a Board of Appeal ${ }^{17}$ and is based in London. ${ }^{18}$ The tasks of the EBA are provided for in Article 8, including that the EBA will contribute to the establishment of high regulatory and supervisory standards, will consistently apply Union law, will facilitate the delegation of tasks to competent authorities, will cooperate closely with the ESRB, ${ }^{19}$ will conduct peer review analysis and to monitor and will assess market developments in its area of competence. It is also provided with the power in Article 8(2) to develop draft technical standards, issue decisions and opinions as well as the power pursuant to Article 34 to provide opinions to the EU institutions in areas related to its own competence. The raison d'etre of the EBA appears to be, however, predominantly the development of standards and guidelines. $^{20}$ National bodies would retain day-to-day oversight powers but the EBA would seek to ensure a common supervisory culture and consistent supervisory practices, ensuring a coordinated response in crisis situations. Moreover, national

\footnotetext{
13 “Spring 2010 Eurobarometer- EU Citizens favour stronger European economic governance" IP/10/1071 (26 August 2010).

${ }^{14}$ Regulation (EU) No. 1093/2010 of the European Parliament and Council of 24 November 2010 establishing a European Supervisory Authority (European Banking Authority), amending Decision No. 716/2009/ EC and repealing Commission Decision 2009 /78/EC.

${ }^{15}$ Article 5.

${ }^{16}$ Article 3, similar to the other ESAs.

${ }^{17}$ Articles 40-58. A decision of the EBA could be appealed to the Board of Appeal.

${ }^{18}$ Article 7. The other ESAs are based in London and Frankfurt, for optical and perceived power- based reasons.

${ }^{19}$ This closeness is in fact mandatory as a matter of law- Article 36 provides that the EBA "shall co-operate with the ESRB".

${ }^{20}$ Articles 7 and 8.
} 


\section{DOES THE EMPEROR HAVE FINANCIAL CRISIS CLOTHES? REFLECTIONS ON THE LEGAL BASIS OF THE EUROPEAN BANKING AUTHORITY}

central banks that were not bank supervisors may attend meetings of the Board of Supervisors in a non-voting capacity. ${ }^{21}$

\section{Powers}

Overall, the EBA holds limited powers, limited responsibilities, limited decision-making functions and cannot adopt general regulatory measures. For example, power is conferred on the EBA to develop regulatory technical standards in certain areas identified in EU financial markets legislation pursuant to Article 10. A detailed procedure is set out there for the adoption of such standards, involving the Commission, then the Parliament and Council as well as public consultation and Bank Stakeholder groups. ${ }^{22}$ The Authority has powers pursuant to Article 15 to implement technical standards by means of implementing acts pursuant to Article 291 TFEU, which are expressly defined "not to imply strategic decisions or policy choices." In both instances, the Commission remains the key decision-maker as to whether to endorse the standards proposed by the EBA and how to proceed, suggesting a definitive hierarchical status of the institutional structure with the Commission at the pinnacle of standards development and questionable independence and accountability of the EBA. ${ }^{23}$ Notably, the EBA would lack enforcement powers itself, which would take place instead through the Commission. ${ }^{24}$ This is because as a matter of EU law regulatory powers cannot be delegated to agencies where the powers are conferred by the Treaties on the EU Institutions, pursuant to the Meroni doctrine. ${ }^{25}$

Moreover, it is provided in Article 18 that the Council, in consultation with the Commission and ESRB and ESA's, may determine the existence of an emergency situation and after this action, the EBA may adopt decisions requiring competent

\footnotetext{
${ }^{21}$ Article 40(4). Axel Weber, President of the Deutsche Bundesbank, had argued that the Central Banks were not adequately represented on the EBA in an earlier format and that only the ECB would be represented on it. He contended that retaining a pivotal role for Central Banks remained of great importance to the power dynamic of Central Banking authorities and their cooperation at EU level:

Weber "The reform of financial supervision and regulation in Europe," Speech delivered at the Institute for International and European Affairs, Dublin, Ireland (10 March 2010). His critique seems only partially answered and the power dynamic remains potentially much more fluid in the new Regulation.

${ }^{22}$ The EBA develops the standards and the Commission adopts them. The regulatory technical standards adopted are delegated acts (pursuant to Article 290 TFEU) and implementing technical standards are implementing acts (pursuant to Article 291 TFEU). Commission delegated acts can supplement or amend certain non-essential elements of Union acts and Commission implementing acts lay down uniform conditions for implementing legally binding Union acts.

${ }^{23}$ Although Ferran suggests that its room for manoeuvre is limited: above, fn. 1, p. 46.

${ }^{24}$ Where a national authority did not comply with an EBA recommendation, Commission would thus be empowered to address a formal opinion to the national supervisory authority, without prejudice to its powers pursuant to Article 258 TFEU to take infringement proceedings: See Article 17(4), where the formal opinion of the Commission shall take into the account the recommendation of the Authority ${ }^{25}$ Case 9/56 Meroni v. High Authority [1957-8] ECR 133. See Griller \& Orator above, fn. 4 and Chamon "EU Agencies: Does the Meroni Doctrine make sense?" (2010) 17(3) Maastricht Journal of European and Comparative Law 281.
} 


\section{DOES THE EMPEROR HAVE FINANCIAL CRISIS CLOTHES? REFLECTIONS ON THE LEGAL BASIS OF THE EUROPEAN BANKING AUTHORITY}

authorities to act. ${ }^{26}$ This hierarchy of powers differs from its earlier legislative format, where the Commission alone remained the key decision-maker in times of crisis. ${ }^{27}$ Where a competent authority does not respond, the EBA may adopt individual decisions prevailing over previous decisions of the competent authority. ${ }^{28}$ So only in the latter situation is the EBA truly empowered and issues remain as to the ability of individuals to challenge the legality of the decision adopted by the EBA pursuant to Article 18(4). It is envisaged in the Regulation that the EBA would be empowered to settle disagreements between national authorities with binding effect and would be empowered to adopt individual decisions to ensure compliance. ${ }^{29}$ It is provided pursuant to Article 33, that the EBA may enter "administrative arrangements" with supervisory authorities, international organisations and the administrations of third countries. Ostensibly, major constitutional questions flow from the nature of the entity that would be created, which could issue decisions, for example, as to a US member of the EBA with which it enters an "administrative agreement" and where, thereafter, issues arise from the impact of EU rules outside of the landmass of the EU. The transnational dimension to this remains critical to global financial stability and yet this provision remains buried deep within the Regulation, not necessarily explicable in light of the internal market roots of the Regulation. Save for some benign references in the Recitals (eg Rec. 17) as to an "internal market in financial services," it is notable that throughout the Regulation the internal market is not the expressed focus of this function but rather the functioning of financial markets and financial systems of the Union, considered further above. All of the above indicates an institution with much potential influence but with limited capacity to agitate and react.

Of importance then for present purposes is the legal basis for the proposed regulation, Article 114 TFEU. The background to the state of the law is outlined here firstly, followed by an analysis of caselaw considering institutional design pursuant to Article 114 and its application to the EBA.

\section{Article 114 TFEU as the legal basis for the EBA}

I. The smoking constitution: the expansive evolution of Article 114 TFEU postTobacco Advertising

As is well-known, Article 114 TFEU has formed the main legal basis for internal market harmonization or approximation of laws. ${ }^{30}$ The Court has a limited record of striking

\footnotetext{
${ }^{26}$ Article 18(3).

27 Proposal For A Regulation of the European Parliament and of the Council Establishing A European Banking Authority (Brussels, 23.9.2009 COM(2009) 501 Final 2009/0142 (COD)), Article 10.

${ }^{28}$ Article 18(4).

${ }^{29}$ See Article 19(3).

${ }^{30}$ Which provides (in part):
} 


\section{DOES THE EMPEROR HAVE FINANCIAL CRISIS CLOTHES? REFLECTIONS ON THE LEGAL BASIS OF THE EUROPEAN BANKING AUTHORITY}

down measures that have been enacted pursuant to Article 114 TFEU. Article 114 TFEU remains largely unaltered by the Treaty of Lisbon, despite the innovations there to "list" legal competences explicitly and involve National Parliaments in both the legislative process and subsidiarity controls. ${ }^{31}$ The threshold test for the legislator to invoke Article 114 TFEU remains that the approximation or harmonisation must have as its "genuine" objective the improvement of the conditions of the "establishment and functioning" of the internal market. ${ }^{32}$ Mere disparities between national laws do not suffice to warrant harmonisation. Rather:

the Community legislature may have recourse to [Article 114] in particular where there are differences between national rules which are such as to obstruct the fundamental freedoms and thus have a direct effect on the functioning of the internal market ... Recourse to that provision is also possible if the aim is to prevent the emergence of such obstacles to trade resulting from the divergent development of national laws. However, the emergence of such obstacles must be likely and the measure in question must be designed to prevent them."33

The Court has had a difficult time persuading the critics of the virtues of the tests set out in its self-proclaimed "consistent" caselaw, ${ }^{34}$ especially its less than rigorous approach

"1....The European Parliament and the Council shall, acting in accordance with the ordinary legislative procedure and after consulting the Economic and Social Committee, adopt the measures for the approximation of the provisions laid down by law, regulation or administrative action in Member States which have as their object the establishment and functioning of the internal market. 2. Paragraph 1 shall not apply to fiscal provisions, to those relating to the free movement of persons nor to those relating to the rights and interests of employed persons...."

${ }^{31}$ See now Consolidated Versions of the Treaty on European Union and the Treaty on the Functioning of the European Union, 2008/C 115/01, p.1, Title I (competence); Categories of exclusive, shared and supporting legislative competence are now provided for, at the outset of the Treaty on the Functioning of the European Union: Schütze “The European Community's Federal Order of Competences-A Retrospective Analysis" in Dougan \& Currie eds. 50 Years of the European treaties looking back and thinking forward (Hart, 2009) p. 63; Schütze "Subsidiarity after Lisbon: Reinforcing the Safeguards of Federalism" (2009) 68 Cambridge Law Journal 525 and Schütze "Lisbon and the federal order of competences: a prospective analysis" (2008) 33 European Law Review 709; Dougan "The Treaty of Lisbon 2007: Winning Minds, not Hearts" (2008) 45 CMLRev. 617, section 6.2; Barrett "The King is Dead, Long Live the King: The Recasting by the Reform Treaty of the Provisions of the Constitutional Treaty Concerning National Parliaments" (2008) 33 European Law Review 66; House of Commons European Scrutiny Committee Subsidiarity, National Parliaments and the Lisbon Treaty (HC 563, 33rd Report of Session 2007-2008), Ch. 3; See Protocol (No. 2) on the application of the principles of subsidiarity and proportionality.

${ }^{32}$ Case C-376/98 Germany v. Parliament and Council (Tobacco Advertising) [2000] ECR I-8419, para. 84.

${ }^{33}$ See Case C-58/08 The Queen on the application of Vodafone Ltd. \& others v. Secretary of State for Business, Enterprise and Regulatory Reform \& others (Mobile Phone Roaming) [2010] I-ECR 0000, Paras 32-33. Earlier caselaw in the 1990s, such as the Working Time Directive decision, had held that Article 114 could not ground the validity of a measure where it had its principal objective rooted in other Treaty provisions, for example, the health and safety of workers: C-84/94 UK v. Council (Working Time Directive) [1996] ECR I-5755.

${ }^{34}$ Mobile Phone Roaming ibid, Paras 32. As Herlin-Karnell states (discussing the decision of the Court in Case C-301/06 Ireland v. Parliament \& Council [2009] ECR I-00593 and the construction by the Court of Article 114 TFEU): "[t]he difficulty is where to draw the line: anything could constitute an obstacle ..." 


\section{DOES THE EMPEROR HAVE FINANCIAL CRISIS CLOTHES? REFLECTIONS ON THE LEGAL BASIS OF THE EUROPEAN BANKING AUTHORITY}

to defining "obstacles" to the functioning of the internal market and the "likelihood" of their materialisation. ${ }^{35}$ However, the caselaw was dramatically coloured by the Tobacco Advertising (No. 1) ${ }^{36}$ decision, which remains isolated as an instance of the Court striking down legislation rooted in Article 114 TFEU. The Court famously held there that Article 114 TFEU did not constitute a "generalised" competence clause for the legislature. There, serious restrictions contained in Directive 98/43/EC on the approximation of the laws, regulations and administrative provisions of the Member States relating to the advertising and sponsorship of tobacco products in various media were struck down by the Court as the directive did not have as its genuine objective the internal market, but rather public health. Tobacco Advertising remains the high water mark of intervention on the part of the Court. ${ }^{37}$

Then in British American Tobacco, ${ }^{38}$ the Court upheld significant tobacco product labelling rules as to health warnings contained in Directive 2001/37/EC concerning the manufacture, presentation and sale of tobacco products. The Court held that national rules laying down such product requirements were, in the absence of harmonisation, likely to constitute obstacles to free movement of goods. Notably, public health considerations clearly motivating the legislation did not operate as a bar to the use of Article 114 TFEU. The decision of the Court has been subjected to significant criticism in so far the reasoning appears unduly formalistic, failing to rigorously consider whether labelling rules truly impacted on free movement. ${ }^{39}$ Swedish Match $^{40}$ is a later and more controversial decision again where the Court upheld an outright ban on the marketing of tobacco for oral use in the same Directive 2001/37/EC, founded upon (principally) Article 114 TFEU. $^{41}$ The Court sanctioned there inter alia the provisional or definite

Annotation, Case C-301/06 Ireland v. Parliament and Council Judgment of the Court (Grand Chamber) 10 February 2009 (2009) 46 CMLRev 1667, 1681.

${ }^{35}$ See Wyatt "Community Competence to regulate the internal market" in Dougan \& Currie eds. 50 Years of the European treaties looking back and thinking forward (Hart, 2009) p. 93; Weatherill "Competence and Legitimacy" in Barnard and Odudu eds, The Outer Limits of European Union Law (Hart, 2009) p. 17; Dashwood "Article 308 EC as the Outer Limits of Expressly conferred Community Competence" in Barnard and Odudu eds The Outer Limits of European Union Law (Hart, 2009) p. 35; Hofmann "Which limits? Control of powers in an Integrated Legal System" in Barnard and Odudu eds., The Outer Limits of European Union Law (Hart, 2009) p. 45; Konstadinides Division of Powers in European Union Law: The Delimitation of Internal Competences between the EU \& the Member States (Kluwer, 2009).

${ }^{36}$ Case C-376/98 Germany v. Parliament and Council (Tobacco Advertising) [2000] ECR I-8419.

${ }^{37}$ A carefully redrawn Directive 2003/33/EC, resulting in a more limited ban, was upheld by the Court in Tobacco Advertising II: Case C-380/03 Germany v. Parliament and Council [2006] ECR I-11573.

${ }^{38}$ Case C-491/01 R v. Secretary of State for Health ex. Parte. British American Tobacco (Investments) Ltd. And Imperial Tobacco Ltd. [2002] ECR I-11453.

${ }^{39}$ Wyatt, supra fn.35, at p. 126.

${ }^{40}$ Case C-210/03 R. On the application of Swedish Match AB \& Swedish Match UK Ltd. v. Secretary of State for Health [2004] ECR I-11893.

${ }^{41}$ But also ex. Article $133 \mathrm{EC}$ and also raising the difficult question of the relationship between ex. Article 95(3) EC (now Article 114(3) TFEU and ex Article 152 EC (now Article 168 TFEU), as to the protection of health and the standard of its protection in harmonisation laws. Special provisions now exist in Article 114 TFEU, paras. 6 and 8 as to health. 


\section{DOES THE EMPEROR HAVE FINANCIAL CRISIS CLOTHES? REFLECTIONS ON THE LEGAL BASIS OF THE EUROPEAN BANKING AUTHORITY}

prohibition on the marketing of a product on account the competence of the legislature to take "appropriate measures" for the purposes of Article 114 TFEU. The deployment of Article 114 to prohibit outright the circulation of products in light of the emphasis in its previous caselaw on the removal of obstacles to trade is perceived by some as an extraordinary expansion of the caselaw. ${ }^{42}$ There are several high profile recent actions for annulment on the basis of the use of Article 114 TFEU which again fail. ${ }^{43}$

The "Tobacco saga" ultimately highlights the ebb and flow of EU constitutional law. The Court has placed less than rigorous limits on the development of Article 114 TFEU and its ambivalent jurisprudence has operated to the advantage of the legislature.

\section{Is the Article 114 TFEU threshold met by the EBA Regulation?}

Firstly, in applying the threshold elements of the Article 114 TFEU caselaw (before and after Tobacco Advertising) to the EBA, the single rationale for the adoption of the EBA legislation pursuant to Article 114 TFEU appears to be that it will contribute to the functioning of the internal market and will strengthen financial stability. It seems apparent, however, that mere "differences" between national banking authority rules did not constitute barriers to capital movements in Europe such as to hinder the functioning of the internal market. ${ }^{44}$ A culture of co-operative supervision appears to be the central plank of EBA. The problems arising global and pan-European finance and banking in fact were significantly more complex and far-reaching than the workings of the internal market. The internal market is very difficult to locate within the operation and functional activities of the EBA and its relationship to free movement is at best tenuous. Secondly, the EBA is a clear example of pan-European "high-level" cooperation and information sharing with "low-level" enforcement powers. However, the ability of national authorities to replicate its functions seems apparent also. Paradoxically, the broader "high-level" ambitions of the EBA and ESFS regime generally are of relevance to any analysis. The "likelihood" of obstacles to the internal market occurring through the lack of an EBA regime is more challenging to refute and the low threshold level of the caselaw inures to the benefit of the legislature, in this regard.

\footnotetext{
${ }^{42}$ See Wyatt supra fn. 35, pp. 130-136.

${ }^{43}$ For example, Mobile Phone Roaming, fn. 33, Data Retention Directive, (fn. 34).

44 The House of Commons has outlined that while it was obviously desirable to avoid financial shocks, it was not clear that the measures inherently related to the single market but rather to the orderly functioning of the financial system: House of Commons Treasury - Sixteenth Report Session 2008-09 The Committee's Opinion on proposals for European financial supervision (11 November 2009). See also Andoura and Timmerman who question the validity of the use of Article 114 TFEU as the legal basis for the EBA: "Governance of the EU: The Reform Debate on European Agencies Reignited" EPIN Working Papers No. 19 (October, 2008). Cf. Ferran \& Alexander "Can Soft Law Bodies Be Effective? Soft Systemic Risk Oversight Bodies and the Special Case of the European Systemic Risk Board" (13 September 2010), available at: http://ssrn.com/abstract=1676140.
} 


\section{DOES THE EMPEROR HAVE FINANCIAL CRISIS CLOTHES? REFLECTIONS ON THE LEGAL BASIS OF THE EUROPEAN BANKING AUTHORITY}

\section{Key Article 114 TFEU decisions involving the design of EU agencies and their powers}

The Court has taken an expansive view of administrative powers and the creation of EU agencies generally and this jurisprudence is informative for further analysis at this point of Article 114 TFEU. However, there is little by way of precedent for a global problem with a pan-European dimension being resolved by way of institutions designed pursuant to Article 114 TFEU. Key decisions of the Court upholding Article 114 TFEU as a basis for creating institutions in harmonisation laws include Germany v. Council (Product Safety), ${ }^{45}$ UK v. Parliament (ENISA) ${ }^{46}$ and UK v. Parliament (Smoke Flavourings). ${ }^{47}$ In all these three decisions, the Court upheld the institution and/ or procedures enacted pursuant to the clause. Indeed, some suggest that the decisions reject a simplistic twolevel model of executive federalism for the EU and a broad view of the administrative law toolbox of the EU. ${ }^{48}$ The decisions are first outlined here and then the application of the caselaw to the EBA is considered in each case thereafter.

The first and earliest of these decisions is indicative of the broad range of powers the Court has sanctioned as regards EU agencies pursuant to Article 114 TFEU. In the Product Safety decision, ${ }^{49}$ Germany had there challenged the powers entrusted to the Commission in Article 9 of Directive 92/59 on general product safety, an early internal market consumer law, adopted pursuant to Article 114 TFEU. The powers were accorded to the Commission so as to allow it to take decisions replacing those which national authorities had taken to ensure compliance with national laws transposing the directive. While the German Government admitted an entitlement of the Commission under the Treaties to supervise provisional measures, it disputed the entitlement of the Commission to adopt such measures pursuant to Article 114 TFEU. The Court upheld the supervisory measures adopted pursuant to Article 114 TFEU $^{50}$ by virtue of the fact that the differences could arise between the measures taken by the States on foot of the Directive itself. $^{51}$ Moreover, the Court stressed that the powers granted to the Commission were to deal with serious and emergency situations, often of last resort. The Court held that the powers were necessitated by the serious and immediate risks to consumers." 52 The emphasis by the Court on the serious and emergency situations arising to warrant the powers is particularly remarkable. Moreover, the schema of the Directive itself, of partial harmonisation giving rise to a situation possibly necessitating a temporary emergency intervention, is far from "ordinary" as a matter of fact and law. Product Safety is then suggested here to be only of partial relevance to the new EBA

${ }^{45}$ Case C-359/92 Federal Republic of Germany v. Council (Product Safety) [1994] ECR I-3681.

${ }^{46}$ C-66/04 UK v. Parliament and Council (Smoke Flavourings) [2005] ECR I-10553.

${ }^{47}$ Case C-217/04 United Kingdom v. Parliament and Council (ENISA) [2006] ECR I-3771.

${ }^{48}$ Hoffman, supra fn. 35, p.57.

${ }^{49}$ See supra, fn. 45.

${ }^{50}$ Described by the Council as "horizontal harmonization" in para. 23.

${ }^{51}$ Para. 30.

52 Para. 34. See paras. 31-34 also. 


\section{DOES THE EMPEROR HAVE FINANCIAL CRISIS CLOTHES? REFLECTIONS ON THE LEGAL BASIS OF THE EUROPEAN BANKING AUTHORITY}

regime. It is hard to find an analogy between the regimes in light of the (predominantly) broader and longer-term ambitions of the EBA Regulation.

Secondly, in the more recent decision of Smoke Flavourings, ${ }^{53}$ the UK challenged the use of Article 114 TFEU as the legal basis to adopt a Regulation (EC) 2065/2003 on smoke flavourings to establish a centralised procedure to authorise smoke flavourings for foods, falling short of harmonisation. A two-stage decision-making procedure on the authorisation of flavourings was established, giving powers to the European Food Safety Authority and the Commission, the latter having to act on an opinion of the former. The UK contended that the measure was unclear as to that which was being authorised and how it was to be evaluated and that the regulation could have been achieved by the simultaneous enactment of identical legislation in Member States.

The Court upheld the use of Article 114 TFEU on the basis that the divergences between national laws and administrative provisions on the evaluation and authorisation of smoke flavourings could have hindered free movement and created unfair competition warranting the use of Article 114 TFEU. ${ }^{54}$ The Court also upheld the structural arrangements where harmonisation was comprised of several stages: here relating to the fixing of criteria and the adoption of a specific list. The Court here held that the legislature had to determine the basic act and the mechanisms to implement those elements, which it had done in this case. Moreover, the Court held that the regulation did not have the incidental effect of harmonising the internal market but rather approximated laws, regulations and administrative provisions of the Member States. ${ }^{55}$

The test employed by the Court here as to the threshold to invoke Article 114 is very broad indeed again. The Court was prepared to uphold mere differences between laws of Member States as warranting legislative intervention pursuant to Article 114 and on this mode of reasoning, surely Article 114 TFEU could provide a valid legal basis for the EBA, even if the internal market remains far from central to the operation and rationale for the EBA. The Court in Smoke Flavourings was prepared to grant reasonably broad regulatory powers to both an agency and an EU institution as an exercise in shared decision-making. The complexity of the EBA regime again, however, does not fall squarely within the parameters of Smoke Flavourings. The EBA has a broader mandate to adopt standards and has broader tasks than the agency in Smoke Flavourings, while the true enforcement of standards under the EBA Regulation lies within the remit of the Commission only. ${ }^{56}$ Thus Smoke Flavourings does not necessarily serve as an appropriate precedent so as to uphold the viability of the EBA Regulation, as power is not distributed in the same way between the EBA and the Commission as between the relevant institutions in Smoke Flavourings.

\footnotetext{
${ }^{53}$ See supra, fn. 46.

54 Para. 42.

55 Para. 58.

56 At the behest of all institutions, the EBA or Banking Stakeholder Groups, the EBA can investigate a breach of EU law: Article 17.
} 


\section{DOES THE EMPEROR HAVE FINANCIAL CRISIS CLOTHES? REFLECTIONS ON THE LEGAL BASIS OF THE EUROPEAN BANKING AUTHORITY}

Thirdly, the decision of the Court of Justice in United Kingdom v. Parliament and Council (ENISA) is expressly invoked in Recital 17 of the EBA Regulation to bolster its legal validity and thus merits close analysis. ${ }^{57}$ In ENISA, the Court upheld the use of 114 TFEU to establish a European Network and Information Security Agency (ENISA), in the face of a competence challenge by the UK. There, the issue arose as to the legality of ENISA, enacted pursuant to Article 1(1) of the Directive 2002/21/EC, establishing a common regulatory framework for electronic communications networks and services. ENISA was intended to enhance the ability of the then Community and Member States to prevent, address and respond to network and information security problems and to provide assistance to these actors and was also empowered to collect information and to enhance cooperation. The UK argued that the instrument achieved no different a result to that which could have been obtained through the simultaneous enactment of legislation in the Member States and the provision of non-binding advice by the agency and its limited and inadequately reasoned powers were impugned by the UK. The Parliament notably argued that the measures amounted to "low-intensity" approximation, leaving national agencies free to exercise their discretion and adopt different measures. ${ }^{58}$ The Court reasoned that the Agency was not created in isolation but rather as a package of measures and the regulatory schema was complex and technologically fast-moving. The Court held that:

"...[In] the light of the characteristics of the subject-matter, the regulation ... forms part of a normative context circumscribed by the Framework Directive and the specific directives and directed at completing the internal market in the area of electronic communications ... the Community legislature considered that ... the Agency was an appropriate means of preventing the emergence of disparities likely to create obstacles to the smooth functioning of the internal market in the area. ${ }^{59}$

Clearly, the reasoning of the Court is particularly broad again with respect to the threshold to invoke Article 114 TFEU and would authorise many infrastructural designs. Moreover, upholding agencies such as ENISA may in fact be consistent with a nuanced sensitivity to subsidiarity and proportionality even in the context of expanded reading of Article 114 TFEU. ${ }^{60}$ However, the scale and ambitions of the ESFS reforms entail, it is suggested here, that subsidiarity is hardly at the root of the recent regulatory reforms in this area, resulting in the enactment of the ESA's and the EBA in particular. There still remains the possibility that regulatory rules could be adopted simultaneously at national level which would achieve the same result as the EBA Regulation. Also, unlike the ENISA entity, there remains the important question of its enforcement deficit, i.e, whether the EBA will be beneficial or necessary without direct enforcement powers and

\footnotetext{
${ }^{57}$ See above, supra fn. 47.

${ }^{58}$ See Gutman "Casenote Case 66/04 Smoke Flavorings; Case C-463/03, SCE; and Case C-217/04, ENISA" (2006/2007) 13 Columbia Journal of European Law 147.

${ }^{59}$ At para. 58 onwards.

${ }^{60}$ Hoffman, fn. 35, p. 57.
} 


\section{DOES THE EMPEROR HAVE FINANCIAL CRISIS CLOTHES? REFLECTIONS ON THE LEGAL BASIS OF THE EUROPEAN BANKING AUTHORITY}

how it could informally coerce third parties (for example, the US) to enforce or consider or adopt its rulings (for example, where it has entered administrative agreements with those countries, pursuant to Article 33). These questions remain unanswered by the Product Safety, Smoke Flavourings and ENISA decisions, indicating the new and unprecedented scale of the financial crisis institutional reforms.

\section{The constitutional and institutional paradox-an EU agency and institutional schema with powers that are too narrow and too broad}

\section{The Paradox}

The EBA does not appear to establish anything close to a supranational regulator at EU level. ${ }^{61}$ Yet a consensus of views had emerged on the necessity for a strong panEuropean solution, from interest groups to EU institutions. For example, the Investment Managers Association had argued that:

"[a] harmonized regulatory and supervisory framework is ... of great importance to the industry: it is very expensive and inefficient to operate under 27 sets of rules, or 27 differing interpretations of the EU rules...There has also been too much gold-plating of the EU rules, with national regulators adding requirements on top of the EU requirements as they see fit. “62

In early 2010, Dominique Strauss-Kahn, the Managing Director of the IMF, argued for the creation of a European Resolution Authority armed with the mandate and tools to deal with failing cross-border banks, an ex-ante solution to the problems that currently hamper cooperation in crisis situations rather than an ex-post one, as part of an integrated system of crisis prevention. ${ }^{63}$ In 2010, the European Central Bank (ECB) delivered an opinion on the proposed financial structures including the powers of the EBA. ${ }^{64}$ On balance, the ECB supported the provisions of the EBA Regulation but had

${ }^{61}$ As Alford states:

"The success of integrating European financial markets, particularly wholesale markets, facilitated by the common currency, the euro, has highlighted the need for improved supervisory coordination among EU regulators. However, colleges of regulators are not supranational regulators."

See supra, fn. 6, at 360 .

62 Quoted in House of Commons Treasury - Sixteenth Report The Committee's Opinion on proposals for European financial supervision Session 2008-09 (11 November 2009) p. 3.

${ }^{63}$ Building a Crisis Management Framework for the Single Market," (Brussels, 19 March 19, 2010): http://www.imf.org/external/np/speeches/2010/031910.htm

${ }^{64}$ Opinion Of The European Central Bank of 18 March 2010 on a proposal for a Directive of the European Parliament and of the Council amending Directives 1998/26/EC, 2002/87/EC, 2003/6/EC, 2003/41/EC, 2003/71/EC, 2004/39/EC, 2004/109/EC, 2005/60/EC, 2006/48/EC, 2006/49/EC, and 2009/65/EC in respect of the powers of the European Banking Authority, the European Insurance and Occupational Pensions Authority and the European Securities and Markets Authority (CON/2010/23). 


\section{DOES THE EMPEROR HAVE FINANCIAL CRISIS CLOTHES? REFLECTIONS ON THE LEGAL BASIS OF THE EUROPEAN BANKING AUTHORITY}

expressed its concerns as to inter alia its limited powers. ${ }^{65}$ The European Parliament Economic and Monetary Affairs Committee had suggested that the EBA should have direct supervision of systemically important cross-border banks, with national supervisors acting as agents of the EBA. ${ }^{66}$

Many now argue that the ESA's, including the EBA, are hindered by their limited constitutional competence and that regulatory law is not well served by such institutions. ${ }^{67}$ It seems clear, however, that the balance struck as regards the powers held by the EBA is founded upon the inherent limitations on the powers of EU agencies generally, pursuant to the Meroni doctrine. Indeed, as Ferran states, there are also sensitive (non-legal) questions involved in empowering the ESA's further- questions of budgets and financing, as well as Member States' domestic politics. ${ }^{68}$ This aside, the unpalatable point remains that the powers of the EBA may be, as a matter of law, both too limited and too broad for the purposes of Article 114 TFEU. The powers of the EBA appear unduly limited to perform its true intended function as set out in the systemic reforms generally. Equally so, paradoxically, the EBA, its raison d'etre and its powers may also be too broad. The EBA does not seem sufficiently nuanced towards internal market considerations, in light of the threshold tests for the use of internal market harmonisation powers, employing a narrow reading of the caselaw of the Court. The fact of the placement of the EBA within a broad package of institutional reforms coordinately placed with other ESA's may render the system "too big to fail." This may deter the Court from revisiting its strong judicial review exercised in Tobacco Advertising I.

\section{Article 352 TFEU (Ex. Article 308 EC) as an alternative legal base for the EBA?}

At this juncture, a brief consideration of an alternative legal basis for the EBA should be mentioned. Certain individuals have advocated the use of Article 352 TFEU as the most appropriate legal basis for the EBA. ${ }^{69}$ Article 352 TFEU remains the other of the "problem children" of the Laeken Declaration. It has a chequered history as a legal basis for exceptional constitutional changes that fall outside the remit of the existing terms of the Treaties requiring, as is well-known, unlike Article 114 TFEU, unanimous voting in

\footnotetext{
65 Ibid, p.4. The ECB stated that as the then proposed Regulation clarified that competent authorities were entitled to share information with the EBA, that it was imperative that all legal obstacles are removed prohibiting the exchange of information between the EBA and the ESRB.

${ }^{66}$ Economic and Monetary Affairs Committee "MEPs vote to beef up financial supervisory package" (10 May 2005) http://www.europarl.europa.eu/news/expert/infopress_page/042-74361-130-05-20-90720100510IPR74360-10-05-2010-2010-false/default_en.htm (last accessed 28 December 2010).

${ }^{67}$ See Ferran \& Alexander supra fn. 44. Ferran, fn. 1, now seems more sanguine on this point: pp. 63-64.

${ }^{68}$ Ferran, ibid.

69 The House of Commons ( $f n .44$ ) has suggested that Article 352 TFEU may provide a better basis for the package, given that it involves legislation being adopted by unanimity.
} 


\section{DOES THE EMPEROR HAVE FINANCIAL CRISIS CLOTHES? REFLECTIONS ON THE LEGAL BASIS OF THE EUROPEAN BANKING AUTHORITY}

the Council. ${ }^{70}$ Precedent exists for the creation of institutions founded upon Article 352 TFEU where no approximation of national laws was envisaged by the institution created, such as European Cooperative Society. ${ }^{71}$ Article 352 TFEU was, as Griller and Orator state, the exclusive legal basis for agencies in earlier times but the Union legislator has made much more use of Article 114 TFEU in recent times. ${ }^{72}$ Article 352 TFEU remains at the margins of acceptability in "constitutional" terms given its continued existence after the Treaty of Lisbon in the face of constitutional changes made to competence. ${ }^{73}$ In fact, the changes made to Article 352 TFEU by the Treaty of Lisbon are slim despite its controversy and reinforce its utility as a flexible exceptional legislative tool. Notably, Article 352 TFEU now provides that the Commission must draw the attention of National Parliaments to the prospective use of the provision and further provides that measures based on the article cannot entail harmonization of Member States law or regulations in cases where the Treaties exclude harmonisation and the article cannot be used as to common and foreign security policy measures. ${ }^{74}$ Thus, there is a legal ring-fence placed upon the contours of the expansion of the powers in the Treaties. This curtailment appears to have no counterpart as to Article 114 TFEU and there is no effort to restrict harmonisation there with formalised institutional ex-ante review, a comparison of remarkable importance. However, there still remains a question of the legitimacy of employing such residual legal tools for institutional solutions to highly exceptional problems of the European Union.

\section{Conclusion}

The lexicon employed by the Commission to explain its institutional proposals, which encompass the EBA, has been in the form of "strengthening financial supervision."75 However, an overall assessment of the EBA Regulation reveals, it is suggested here, a mere co-operation and information regime. The EBA Regulation does not appear to be adequately nuanced towards the caselaw of the Court as to the threshold to invoke

70 But see famously Opinion 2/94 Accession by the Community to the European Convention for the Protection of Human Rights and Fundamental Freedoms [1996] ECR I-1759 and see generally Weatherill "Competence creep and competence control" (2004) 23 Yearbook of European Law 1

${ }^{71}$ Case C-436/03 Parliament v. Council (ECS) [2006] ECR 1-3733, upholding Regulation No. 1435/2003 on the Statute for A European Cooperative Society.

${ }^{72}$ See generally for an excellent survey, Griller \& Orator, supra fn. 4.

${ }^{73}$ As Dashwood (supra fn. 35) states, at p. 40:

“...I believe Article 308 can still perform a useful and constitutionally proper function by allowing the powers of the institutions under specific legal bases to be supplemented, where this proves necessary to attain the Community objective for which the power in question has been conferred."

74 It is also limited by the provisions of a Declaration, emphasising that the Article may not be used to effectively amend the Treaties: see Declaration No. 42 on Article 352 of the Treaty on the Functioning of the European Union.

${ }^{75}$ Communication from the Commission "European financial supervision" COM(2009) 252 final; SEC(2009) 715 SEC(2009) 716. 
DOES THE EMPEROR HAVE FINANCIAL CRISIS CLOTHES? REFLECTIONS ON THE LEGAL BASIS OF THE EUROPEAN BANKING AUTHORITY

Article 114 TFEU. It has been contended here that on the one hand, the EBA is far too limited as an entity in light of its broad-ranging objectives to resolve the pan-European dimension to a global question, and on the other hand, that it goes too far relative to its legal base. As always, the position of the Court on this paradox remains the critical question, given the ramifications for strong and weak judicial review. However, the likelihood of "interventionist review" of this wide-ranging institutional package on the part of the Court remains far from certain. Rather, the Court may be unwilling to say that the Emperor has no clothes. 